Tjalling C. Koopmans Research Institute Thlligh Roopmen

Discussion Paper Series nr: 08-13

\title{
Globalisation, Tax Competition and the Harmonisation of Corporate Tax Rates in Europe: A Case of Killing the Patient to Cure the Disease?
}




\section{Tjalling C. Koopmans Research Institute Utrecht School of Economics \\ Utrecht University}

Janskerkhof 12

3512 BL Utrecht

The Netherlands

telephone $\quad+31302539800$

fax $\quad+31302537373$

website www.koopmansinstitute.uu.nl

The Tjalling C. Koopmans Institute is the research institute and research school of Utrecht School of Economics.

It was founded in 2003, and named after Professor Tjalling C. Koopmans, Dutch-born Nobel Prize laureate in economics of 1975.

In the discussion papers series the Koopmans Institute publishes results of ongoing research for early dissemination of research results, and to enhance discussion with colleagues.

Please send any comments and suggestions on the Koopmans institute, or this series to M.vanDort@econ.uu.nl

ontwerp voorblad: WRIK Utrecht

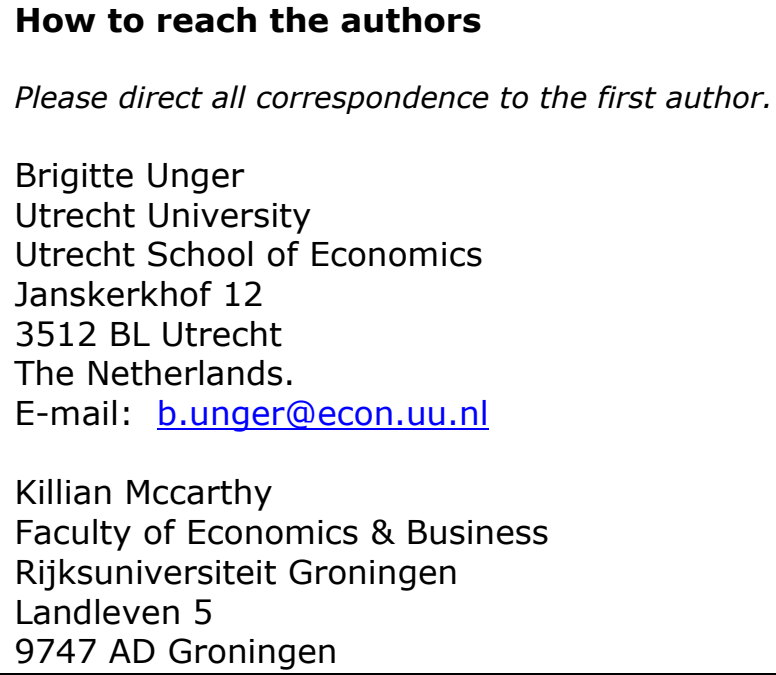

Please direct all correspondence to the first author.

Brigitte Unger

Utrecht University

Utrecht School of Economics

Janskerkhof 12

3512 BL Utrecht

The Netherlands.

E-mail: b.unger@econ.uu.nl

Killian Mccarthy

Faculty of Economics \& Business

Rijksuniversiteit Groningen

Landleven 5

9747 AD Groningen

This paper can be downloaded at: http://www.koopmansinstitute.uu.nl 
Utrecht School of Economics

Tjalling C. Koopmans Research Institute

Discussion Paper Series 08-13

\title{
Globalisation, Tax Competition and the Harmonisation of Corporate Tax Rates in Europe: A Case of Killing the Patient to Cure the Disease?
}

\author{
Killian McCarthy \\ Frederik van Doorn ${ }^{\mathrm{b}}$ \\ Brigitte Unger ${ }^{b}$ \\ ${ }^{a}$ Faculty of Economics \& Business \\ Rijksuniversiteit Groningen \\ ${ }^{\mathrm{b}}$ Faculty of Law, Economics and Governance \\ Utrecht University
}

May 2008

\begin{abstract}
This paper surveys the literature on tax competition, and uses it to analyse current European proposals to harmonise corporate tax rates. It begins, in the course of Section One, by introducing the phenomenon of international tax competition, and illustrates, with the use of secondary research, the reality of the regulatory 'race to the bottom'. Section Two, however, demonstrates the harmful consequences of tax competition - with reference to the immobile factors of production - and makes obvious the necessity of effective intervention. Section Three then introduces and evaluates the calibre of the current proposals to tackle tax competition through collusion and harmonisation, and concludes negatively in the process. As illustrated in this discussion, any efforts to harmonise corporate taxes above the international equilibrium will not only fail to solve the problem at hand, but will exacerbate them, and may even serve to undermine and destabilise the political Union. Section Four then introduce an alternative solution to the problem - in the form of the residence principle - and Section Five concludes.
\end{abstract}

Keywords: International Competition; Europe; Public Finance; Taxation; Regulation

JEL classification: E62; E65; F41; F42; H26; H87; O52; 


\section{INTRODUCTION}

Over the course of the century, deregulation, liberalisation and increased capital mobility created the phenomenon of the multinational firm and, between 1969 and 2002, allowed them both to proliferate - growing from 7,258 to more than 63,000 (Drucker, 2005) - and thrive. So successful were they in fact that by the end of the century, somewhere between twenty-nine and fifty-one of the world's largest economic entities were private multinationals firms ${ }^{1}$. General Motors, for example, was 'economically' more significant than Denmark in 2002, and DaimlerChrysler more significant than Poland, while Royal Dutch Shell, IBM and Sony were each more important then Iran, Ireland and Pakistan. Taken together, the world's top twohundred firms accounted for about $27 \%$ of global economic activity in 2000 , and earned an income greater than the world's poorest 1.2 billion people (Anderson and Kavanagh, 2000). As the process of globalisation continues to knit national economies into a world economy, however, and as everything from banking to telecoms, energy and manufacturing slowly falls under private control, ordoliberal fears of an undemocratic centralisation of power are fast being realised (Schmitz, 2002), and concerns are being raised on the question of taxation.

\section{Figure 1: Foreign Direct Investment Overlaid with a Trend Line}

Source: Data supplied by the United Nations (1996; 2001; 2004; 2007), prepared in Excel and overlaid with a trend line. Discounting for the shock that was $9 / 11$, the upward trend in FDI flows is obvious.

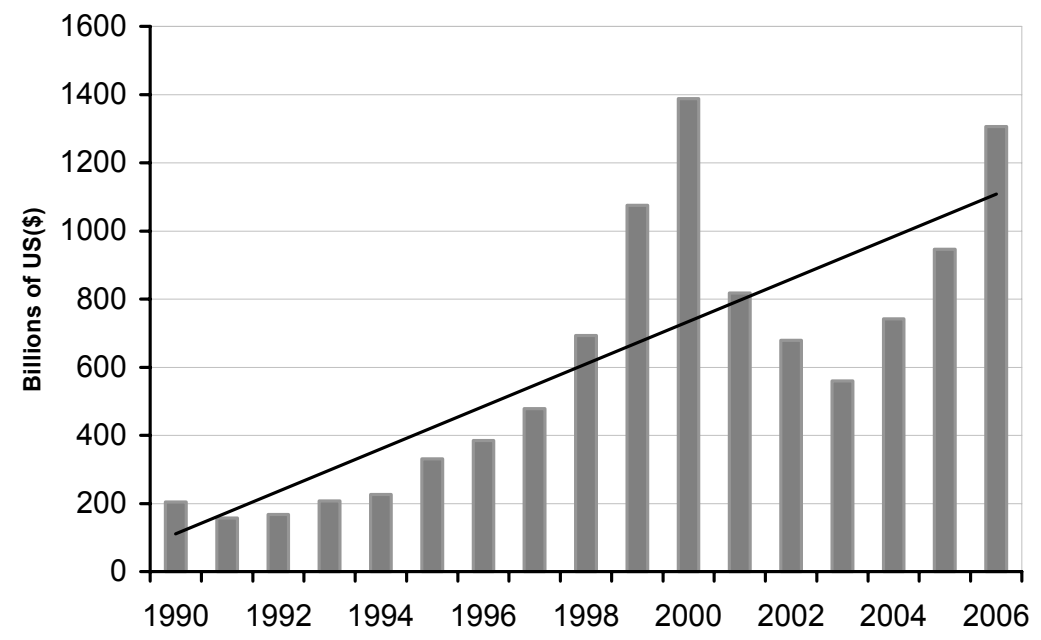

Traditionally, the payment of taxes has been obliged of all individuals or legal entities within a state, and has been levied for a variety of reasons. The provision of public goods such as military defence, the redistribution of wealth, and the protection of private property are all typically put forward examples (Mueller, 2003). According to Alexis de Tocqueville (1840), government is the "shepherd" to the "flock of timid and industrious animals" that is the civil nation, and so by merely funding the state, the payment of taxes can be seen to have played a

\footnotetext{
${ }^{1}$ UNCTAD (2002) finds that twenty-one of the world's top economic entities are corporations - as measured in terms of purchasing-power-parity - whereas Anderson \& Cavanagh (2000), through a comparison of corporate sales and GDP, finds that fifty-one of the hundred are multinationals.
} 
role in liberating man from a Hobbesian 'state of nature' (Hobbes, 1651). It is government and government alone which equates rich and poor, provides public goods and secures private property, and for this reason, taxation has been at the very core of the sovereign state since time immemorial. The right to tax is and has always been a mark of power and legitimacy, and since the time of Cicero, the responsibility to pay has been the 'honour' of citizenship.

Empirical studies have documented, however, that as foreign direct investment (FDI) has risen in recent times (Figure 1) the 'honour' of taxation has diminished. One study of US multinationals (Altshuler, Grubert and Newlon, 2002) for instance, discovered that FDI had become increasingly sensitive to taxes between 1984 and 1992; with results for 1992 suggesting that countries with tax rates ten-percent higher than the average receiving thirtypercent less US FDI when controlling for other factors. And while subsequent reports have shown variable and often less dramatic elasticities ${ }^{2}$, the consensus finds "strong evidence" that direct investment flows are "positively and significantly" affected by tax systems (International Monetary Fund, 2004). Hines (1999) suggests that "taxation significantly influences the location of FDI, corporate borrowing, transfer pricing, dividend and royalty payments", and Sullivan (2002) finds that, at least in the European context, countries with a "favourable tax regime" have "significantly larger inflows of FDI" than their higher-tax counterparts ${ }^{3}$.

As predicted by Tiebout theory (1956), it therefore appears that globalisation - broadly defined as a process by which the whole world becomes a single market, wherein goods, services, capital and labour are traded on a worldwide basis, and where information and the results of research flow readily between countries - has empowered the multinational to "vote [for market liberalising economic policies] with their feet" (Glomm and Lagunoff, 1998). In this world, however, the government of an open economy can have no interest in increasing tax rates above that of the international equilibrium, for to do so would simply drive away investment, and stimulate a capital flight ${ }^{4}$. In the new economic climate, countries are therefore pressurised not only to keep taxes low, but are also incentivised to reduce even further. As a result, however, the ability of the state to pursue independent economic policies has been greatly compromised, if not destroyed, and the once proud nation state has been reduced to the point of being little more than a beggar at the plate of the multinational. The options its faces now are either 'forge ahead' with pro-business deregulation and market liberalisation - and in

\footnotetext{
${ }^{2}$ Broekman and van Vliet (2001) using a panel of FDI inflows in EU countries find elasticities of between 1.4 and -2.2; Devereux and Griffith (1998) using a panel of US multinationals investing in EU countries finds elasticities of -0.4 for the UK and -1.7 for both France and Germany; Devereux and Freeman (1995) with a panel of outward FDI in 7 OECD countries between 1984 and 1989 finds elasticities of -0.4 ; Altshuler et al (2001) studies US outward investment in 58 countries in 1984 and reports results of -1.5, increasing to -2.7 in 1992; Hines and Rice (1994) study outward investment into 73 countries in 1982 and reports elasticities of -3.3; Grubert and Mutti (1991) studies US investment into 33 countries in 1982 and finds elasticities of -0.3 ; Hines (1999) reports results a consensus estimate of -1.7 based on time series models for US investment abroad; and Devereux (1992) surveys the literature and concludes that there are "significant negative effect of taxes on foreign investment".

${ }^{3}$ Sullivan (2002) Four European countries in particular with "favourable tax regimes" - namely Ireland, the Netherlands, Luxembourg, and Switzerland - were found to attracted $38 \%$ of US FDI to Europe between 1996 and 2000; despite accounting for only $9 \%$ of EU GDP.

${ }^{4}$ Gorter, J. and R.A. de Mooij, (2000) illustrates the increasing ratio of intangible to tangible capital investment in six EU countries (Austria, Belgium, France, the Netherlands, the United Kingdom and Sweden), over the period 1990 to 1997 , from 0.4 to 0.55 .
} 
so doing succumb to the international deregulatory 'race-to-the-bottom' - or remain on the moral high-ground, and 'fall behind' in the investment race of the twenty-first century.

No state, however, can afford the cost of falling behind - be it for social, political or economic reasons - meaning that the deregulatory race-to-the-bottom (Sinn, 2003) is all but inevitable. International tax competition - defined as a governmental strategy of attracting foreign direct investment (FDI) by minimising the overall taxation level - is the result of this pressure. Rising trade and investment flows, greater labour mobility, and rapid transfers of technology has meant that the majority of industrial nations have been forced to reduce commercial tax rates in recent years, and in doing so have pushed the average top corporate tax rate in the OECD down from 41.6\% in 1982 to $25.1 \%$ in 2007 (Figure 2). Amongst these, Austria, Germany and Ireland have all cut their rates by more than twenty-five percent, while another six countries have cut theirs rates by more than fifteen-percent; tightening the tails of the tax range from between $55 \%$ and $28 \%$ to between $34 \%$ and $12.5 \%$ in the process ${ }^{5}$.

Figure 2: Declining Corporate Tax Rates in OECD member states Source: Compiled from figures of the OECD Tax Database ${ }^{6}$

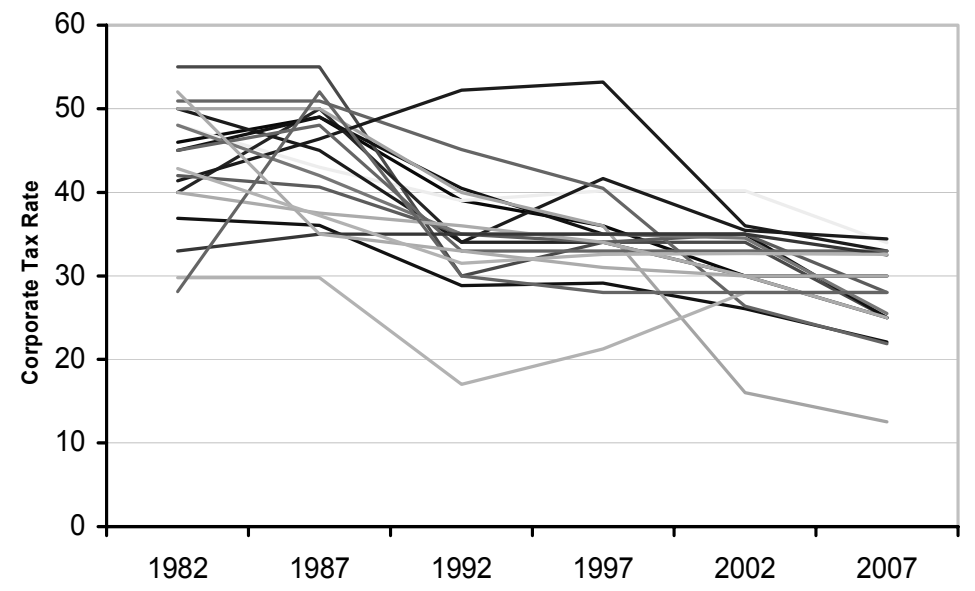

To some commentators, international tax competition produces a situation in which politicians are "forced to keep tax rates reasonable" (Edward and de Ruby, 2002). As we will show in the course of Section Two, however, tax competition results in a dangerous situation, and is not only degrading to the state, but destructive, wasteful and socially inequitable. Because budgets must be balanced, lower corporate taxes imply higher labour taxes must be levied to makeup the difference, and so tax competition inevitably produces a situation which punishes the immobile (labour) factors of production for being immobile. This, we suggest, make the term "harmful" nothing if not an understatement, and requires action if government is to fulfil its mandate. Government, it must be remembered, has been empowered 'by the people

\footnotetext{
${ }^{5}$ This range ignores Switzerland; an outlier amongst the OECD for historical reasons. Despite an initially low rate, however, (of $10 \%$ in 1986), the same downward trend has been observed in Switzerland, and rates have been cut by some $20 \%$ over the period, to $8 \%$ in 2000 .

${ }^{6}$ http://www.oecd.org/ctp/taxdatabase
} 
and for the people' (Lincoln, 1863), and so a process whereby the wealthy multinational benefits at the cost of the poor uni-national is intolerable in the extreme ${ }^{7}$.

To its credit, the European Union is acutely aware of this inequity, and in recent years has proposed a pan-European system of tax harmonisation in an effort to tackle it; a proposal which we will briefly outlined in the course of Section Three. However, as we will show, both the theoretical and empirical evidence suggests that these tax harmonisation plans not only contains the potential to exacerbate the problems they were designed to solve, but to intensify regional economic variances, and undermine the very foundations of the European Project. It will therefore be argued in this paper that not only is tax harmonisation not the economic panacea it is often thought and argued to be, but that it cannot be adopted as a solution to the problem at hand. Instead, and in the course of Section Four, an alternative solution will be proposed by this paper, and its economic and theoretic feasibility will be commented upon in this discussion, and indeed in Section Five. With this, the paper will then conclude in Section Six with a robust, well founded policy suggestion for the future of tax competition policy in Europe, and will point to a number of research questions which must be addressed in future.

\section{The Problem of HaRmful tax Competition}

To many economists tax competition is little more than an issue of supply and demand. International investors with mobile capital demand a low-tax environment in which to do business and, through the process of policy competition, states compete for the elusive point of tax equilibrium - that is, the reconciliation of supply-and-demand - necessary to attract, by lowering taxes relative to those of their rivals. Here, taxes are little more than a dreaded market distortion, markets are essentially robust and that competition between states will ensure the maximisation of welfare. Tax competition therefore is simply a mechanism by which the market can move towards achieving the utopian position of perfect competition, because governments which do not face competition operate like private monopolists and have little incentive to reduce waste or increase quality (Roin, 2001). The process of tax competition should, accordingly, not be feared, prevented or corrected, but rather it should be applauded and respected for contributing to economic efficiency.

Although there may be certain truths in this line of thinking it is not, however, the belief of all economists. Firstly, it has been recognised that not all forms of competition are constructive, and that competition is not necessarily per se good (see Sullivan, 1995 for an example of this discussion). Secondly, and even if this wasn't the case, the appropriateness of the state competing for investment in a manner similar to how a firm competes for customers has been questioned. In modern economic theory, the existence of the state, it has been suggested, is legitimised only by its role in managing market failures - to paraphrase, rendering onto Caesar the things that are Caesar's and onto the market the things that are the markets.

\footnotetext{
${ }^{7}$ Abraham Lincoln: "... that this nation, under God, shall have a new birth of freedom -- and that government of the people, by the people, for the people, shall not perish from the earth." (Gettysburg Address, Gettysburg, Pennsylvania, November 19, 1863)
} 
As a result, many mainstream economists condemn intra-state tax competition as being something both outside the scope of a state's operational portfolio and as essentially destructive in nature. As a case in point, an OECD (1998) report identified six negative effects of low-tax regimes, and concluded that the net result of international tax competition will be a shift in the burden of taxation from the mobile (capital) to the immobile (human) factors of production. To understand why, we will attempt, in the course of this section, to explain this line of reasoning by outlining both the economic theory and by providing empirical evidence of its reality. In doing so, we will robustly conclude on the inescapably harmful nature of tax competition.

\section{1 - The Standard Argument}

\subsection{1 - The Theoretical Standard Argument}

The theoretical standard argument, upon which much of the literature on tax competition is based, suggests that the imposition of a tax on internationally mobile capital, in an open and dynamic economy is impossible, as capital will always be able to shift the burden of taxation. Accordingly, the effects of the imposition of a source tax are twofold: firstly, the increased tax will drive away mobile capital and stimulate a capital flight; and secondly, the tax will cause both the domestic product, and the marginal productivity of the complementary immobile factors, to fall. The crucial point is that the income of these factors declines at a rate greater than it would if the factors were to pay the tax themselves. On the basis of this, tax competition in the modern globalised world means overall losses to the society and an overburdening of the labour factor.

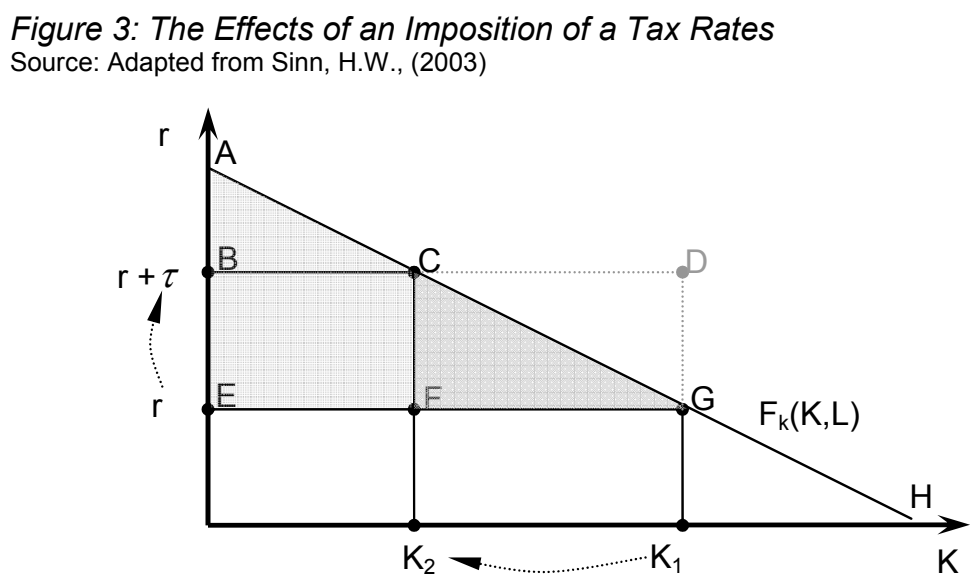

This argument is graphically represented in Figure 3 wherein the decision situation of a single country is illustrated. Here, and summarising Sinn (2003), the country is seen to produce homogenous output according to the downward sloping production function $f(L, K)$, using a fixed and constant amount of labour $(L)$, and a variable amount of internationally mobile capital $(K)$ available at any amount and at the net world market return, $r$. The downward slope illustrates the marginal product of capital. Where there is no tax, the profit-maximising firm invests up to the point $f_{k}=r$, and chooses the investment amount of capital $K_{1}$. The imposition of a source tax levied on capital to the value to $\tau=B E$, however, stimulates a capital flight, and the level of 
capital invested is seen to fall to the new equilibrium point of $K_{2}$. As the net return $r$ is given by the world market, capital leaves the country until its net marginal product after tax is again equal to the given world market of $f_{k}-\tau=r$. The result then is that the tax burden is shifted completely to the immobile factor, causing the wage income to fall from AGE to ACB. The tax revenue BCFE - is obviously smaller than the reduction in wages; which is BCGE. Even if total tax revenue were paid to the wage earners, they would still face a loss of CGF. Attempting to tax mobile capital thus serves only to hurt the immobile element more. The equilibrium in tax competition between states is therefore $K_{1}$

\subsection{2 - Empirical Proof of the Standard Argument}

In full accordance with microeconomic principles, the predictions outlined above are derived from general equilibrium models. The implications are, however, anything but new. More then two centuries ago, Adam Smith noticed that heavy taxes on mobile stock or capital

would cause a loss to workers and the economy ${ }^{8}$. It is thus very surprising that most of recent empirical studies obtain almost inverse results ${ }^{9}$. It has, however, been suggested that a closer look at these empirical results reveals severe problems and deficiencies of both an economic and econometric reasoning (Bretschger and Hettich, 2002). Nevertheless, to accept the 'standard' line of argument, we need to see empirical evidence of a post-globalisation shift of the tax burden, and an important paper by Bretschger and Hettich (2002) provides just this.

This study considers a panel of 14 OECD countries over the period 1967-96 and produces two interesting results. Firstly, the study finds that globalisation has a negative and significant impact on corporate taxes. In a regression model with 303 observations, and using corporate tax rate as the endogenous variable, the study finds coefficients of -19.02 for the variable 'openness' - defined as the degree of integration of the countries in the world economy - significant at the $1 \%$ level, and so robustly proves the negative relation between globalisation and corporate tax burdens. The study argues that while, on paper, corporate tax rates as a percentage of GDP (cogar) seem to have increased in the OECD, the un-weighted 'effective' corporate tax rate (corptax) - that is, the net rate paid by the firm - has sharply declined. The effective corporate tax rate for all countries increased from the late sixties and early seventies, it

\footnotetext{
${ }^{8}[\ldots .$.$] [Land] is a subject which cannot be removed, whereas stock easily may. The proprietor of land is$ necessarily a citizen of the particular country in which his estate lies. The proprietor of stock is properly a citizen of the world, and is not necessarily attached to any particular country. He would be apt to abandon the country in which he was exposed to a vexatious inquisition, in order to be assessed to a burdensome tax, and would remove his stock to some other country where he could either carry on his business, or enjoy his fortune more at his ease. By removing his stock he would put an end to all the industry which it had maintained in the country which he left [...] A tax which tended to drive away stock from any particular country would so far tend to dry up every source of revenue..." (Smith, 1776)

${ }^{9}$ For instance, in a panel regression of 15 OECD countries for the period 1976-90, Garrett (1995), finds that a rising exposure to international trade, which is used as a proxy for financial liberalisation, leads to an increase in capital taxation. Referring to cross-country studies of economic growth, Quinn (1997) considers a broader range of 64 countries with annual data averaged over the years 1974-89. It concludes that corporate taxation is positively associated with financial liberalisation under a wide variety of different model specifications. These findings are supported by Swank (1998) in which a panel regression for 17 industrialised countries (mainly OECD countries) for the period 1966-93, finds that three different measures of capital mobility are positively related to the proxy of corporate taxation. A more recent paper, Simmons (2006) overviews trends in OECD statistics and notes the shift in the burden of taxation.
} 
is suggested, to a level of more than $41 \%$, and then entered a period of serious decline (1992 1996), ending at $34 \%$. This trend is summarised in Figure 4 , wherein corptax is the bold line.

Figure 4: The Effective Corporate Tax Rate Pitched Against Labour Tax Source: Adapted from Bretschger and Hettich, (2002)

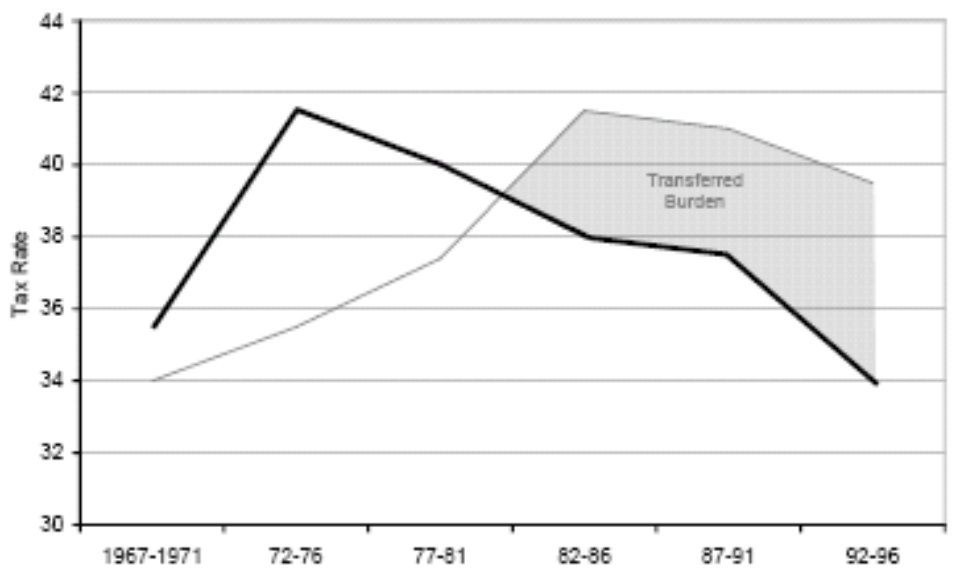

Secondly, and given that the state must be financed, the paper then investigates if there is a corresponding rising labour tax trend, and so a transfer in the tax burden. When analysing the equations with labour tax rates (labtax) as the endogenous variable, for example, the investigation find that globalisation "has a significant [and] positive impact on labour taxes". The degree of integration, measured again by the variable open, produces a positive result 0.97 . Again, when the effects of size are eliminated from this with open(-1), and are lagged in openness 1 , the results hold relatively constant at 0.98 and 0.91 respectively. These results are robust at the $1 \%$ level, leading the authors to conclude that "globalisation has a very clear and significant impact on the relation between labour and corporate taxes". The authors note, however, that the sign of size changes compared to corporate taxes; illustrating that the smaller the countries are, the greater the requirement to lower corporate tax rates, and to compensate for these revenue drops with higher labour rates. This corresponds closely with the 'results on the ground', where it is observed that corporate tax havens are often smaller countries.

Such findings, while impressive, are far from unique. Winner (2005), for example, conducted a time series analysis of the average effective tax rate on capital income and labour income for 23 OECD countries over the period of 1965 to 2000 , and comes to similar conclusions. The study finds that while the consumption tax burden has been almost stationary over the period, the average effective tax on labour has grown steadily - from $21 \%$ to $40 \%-$ and capital tax rates have declined (Figure 5a). Until 1976 the corporate tax burden moved more or less simultaneously with labour-based taxation - increasing from $21 \%$ to around $30 \%$ but from the late 1970's, political attitudes changes towards FDI and the tax burden on capital is seen to decrease from $33.8 \%$ to $28.6 \%$. This indicates that the tax burdens on labour and capital have drifted apart over time - and especially so since the 1980's - and again graphically supports the claim that tax competition has induced a shift of tax burden from capital to labour. 
The study continues to consider these facts in regression form; investigating the robustness of the relationships between the tax rates, country size and the degree of capital mobility, and the intensification of tax competition over time. A static model is used in estimating the interaction effects between capital mobility and the fixed time effects; the results of which are summarised in Figure 5b. Here, a negative (positive) entry indicates a negative (positive) effect of capital mobility on factor income taxes in the corresponding year (and the dotted points denote significance at least at the $10 \%$ level), and so the results point to the increasingly negative impact of capital mobility on capital tax burdens. Until the mid-1980's, we are not able to identify any significant effects of capital mobility on capital tax burden, but since then we observe negative coefficients throughout. This confirms the widely held belief that tax competition has intensified in recent years, and implies that as the pace of globalisation has quickened, it has induced a systematic shift from capital to labour tax burdens.

Figure 5a (Left) The Transferred Burden, and 5b (Right) Capital Mobility \& Capital Tax Source: Adapted and modified from Winner (2005)
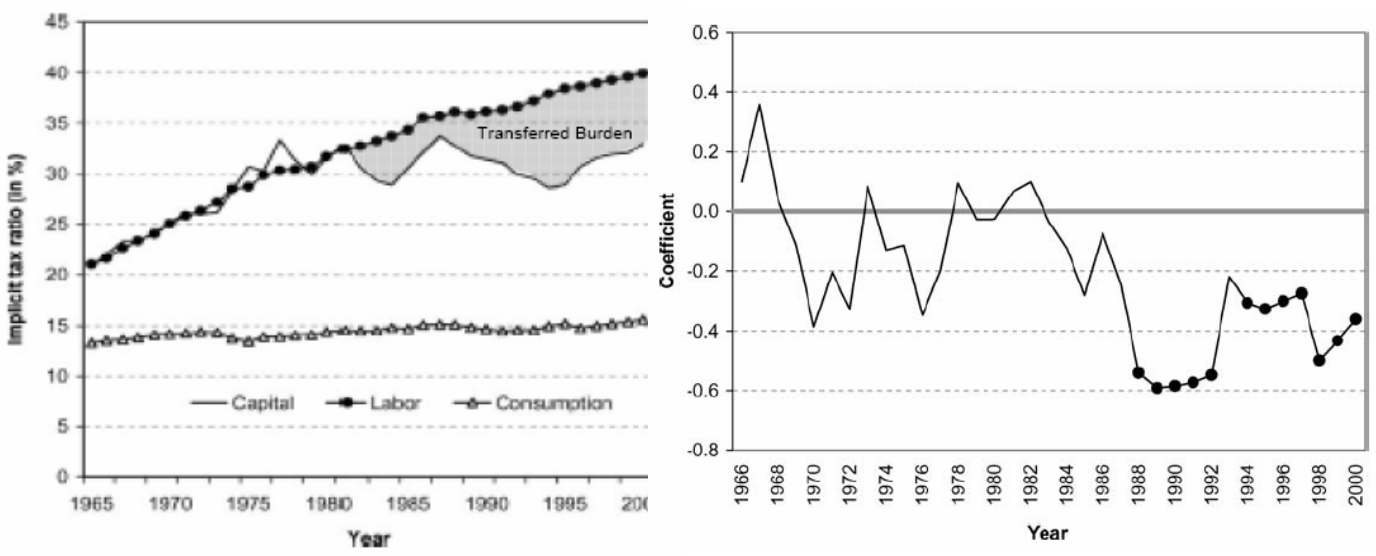

\section{Paper Position 2: The Standard Argument}

On the basis of this we conclude positively on the robustness of the evidence in support of the standard argument of tax competition. In this, we therefore accept the theory that capital taxation is negatively related to the degree of international capital mobility, and that labour taxation relative to capital taxation is positively related to international integration of national economies, and that capital mobility results in a capital tax rate that is sub-optimally low from a societal perspective.

\section{2 - The Infrastructure Argument}

\subsection{1 - The Theoretic Infrastructure Argument}

On the basis of this argumentation, the suggestion is that you cannot tax the mobile element - the capital element - for to do so would cause a reduction in the capital base and a simultaneous overburdening of the immobile, labour element. However, the role of government 
infrastructure investment is often used as evidence against this pessimistic view of policy competition (Sinn, 2003). This line of argument suggests that if taxes are seen as the price that must be paid for publicly provided infrastructure - whereby infrastructure refers to anything provided by the government for the benefit of the firm - the investors will accept them; ergo, destructive policy competition does not have to be feared. Unfortunately, however, empirical studies have shown this to be based on the unrealistic assumption that infrastructure is a pure public good. In reality infrastructure is an impure public good with negative externalities; where externalities are the difference between the marginal private and social costs (Mueller, 2003).

A more realistic impure public good extension to the model is possible with the contribution of the literature on highway congestion models. In this, it is assumed that using a highway incurs: a private cost $c(K, W)>0$, which is based on the number of usage acts, $K$, and is proportional to the capacity of the infrastructure provided by the government, $W$. The properties of the usage function are therefore $c_{k} \geq 0$ and $c_{w}<0$; where $c_{k}>0$ indicates an impure public good, rivalrous in consumption (Mohring and Harwitz, 1962). It is assumed that the function $c$ is homogenous of degree $\lambda$. The total usage cost of the public good is $c(K, W) \cdot K$ and, the total cost for the provision of the public good is $\rho \cdot W$; and it is assumed that a homogenous output is produced according to the linear production function $f(K, L)$, wherein capital $(K)$ is completely internationally mobile, with a return, $r$, and $(L)$ is immobile. The country has only a source tax on capital and a head tax on labour available to it, and these are raised at the rates $\tau$ and $\omega$ respectively. In this situation, the profit maximising firm invests capital up to the point where the marginal product of capital is equal to the sum of the marginal interest rates, usage and tax costs: $f_{k}(K, L)=r+c(K, W)+\tau$. At this point, however, this firm only considers the associated marginal private costs, investing to point $K_{1}$ - and the free market economy floods the infrastructure (Figure 6).

Figure 6: An Inequitable Situation Source: Adapted from Sinn (2003)

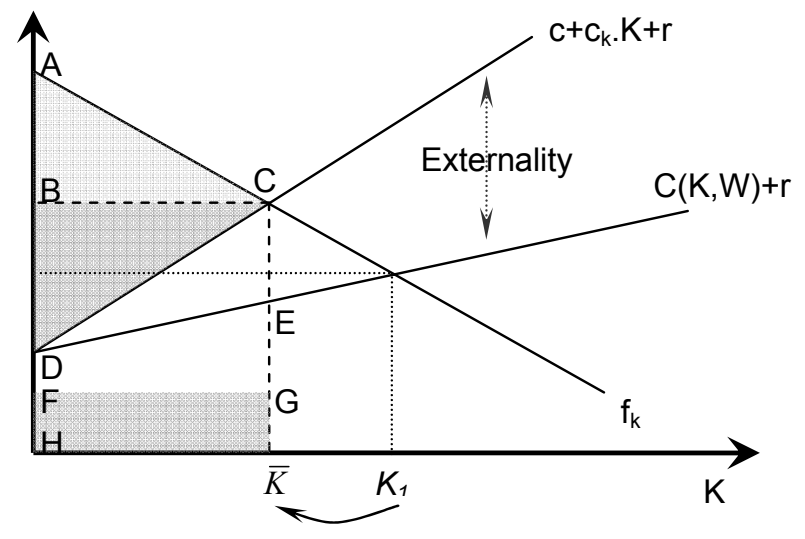

The firm does not, however, consider the marginal social usage costs $c+c_{k} \cdot K$, where $c_{k} \cdot K$ is the marginal congestion externality, in its planning. The difference is left to the government to 
fill with its choice variables: $\tau$ and $\omega$. The lump sum labour tax rate, $\omega$, is endogenously determined so that the government budget is balanced: $\omega L=\rho W-\tau K$. If the tax on capital therefore generates more revenue than is needed for the provision of the public good, there will be a subsidy to labour to balance the budget. The government's aim, however, considering these constraints, is to maximise the rents, $R$, of the domestic residents, $\left(R=\left(f-f_{K} K\right)+r \bar{K}-\right.$ $\omega L)$; where $R$ is what is needed to cover a potential deficit in the provision of the infrastructure. The combination of these gives an expression which shows that the total rent can also be expressed as the difference between the output and the sum of the interest cost in the imported capital, the total usage costs and the total cost of providing the public infrastructure $(R=f-r(K$ $-\bar{K})-c(K, W) K-\rho W)$, and contains an implicit tax shifting result which is due to the fact that firms adjust competitively to the given world market of interest.

Given that the single country can take the total capital income as given, and the labour tax clears the budget, variations in the usage cost of providing the infrastructure are fully absorbed by the income of the immobile factor. Knowing this, the government tries to adjust the tax rate and the capacity of the public good in a way that maximises the rent of domestic citizens. The first-order conditions for a national policy optimum require: firstly, that the marginal product of capital equals the marginal social cost of capital; that is, $f_{k}=r+c+c_{K} K$; and secondly, the satisfaction of the Samuelson condition for the optimal provision of public goods, whereby the sum of all users' marginal willingness to pay is equal to the marginal cost of providing the infrastructure; $-c_{W} K=\rho$. From this we can see that to achieve the optimum, the government must set a tax rate equal to the marginal congestion externality. This optimum tax ( $\tau=\mathrm{c}_{\mathrm{K}} \mathrm{K}$ ) designed to include the total social cost and prevent the abuse of infrastructure, however, increases the imposition of taxation on the capital element. This induces a reduction in investment, as illustrated above, and so the question then arises as to whether or not there is sufficient income from the capital tax revenue to pay for the cost of the infrastructure. It can be shown that the optimal congestion charge is sufficient if and only if $\lambda \geq 0$; that is, when the usage cost function does not have a negative degree of homogeneity ${ }^{10}$. If, however, $\lambda<0$ there will be a fiscal deficit that must be covered by taxing the immobile factor.

The conclusion from this is that only when there are falling or constant returns to scale will marginal cost pricing generate enough revenue to cover the total cost of production. If there are increasing returns to scale, there is a financing deficit that has to be covered elsewhere supporting the view that wage earners will be the victims of systems competition. The 'selection principle' - that is, the suggestion that there must be a fundamental selection bias on behalf of the government towards those activities which have proved to be unsuitable for private markets (Sinn, 1997) - and an overview of the literature on the theory of clubs, confirms this hypothesis (Buchanan, 1965; Broadway, 1980; Berglas and Pines, 1981). This implies that if the state limits itself to the provision of those public goods for which $\lambda<0$, an efficient charge for the use of the

${ }^{10} c_{K} \cdot K+c_{w} \cdot W=\lambda c$ where $\lambda$ is the degree of homogeneity of the usage cost function $c(K, W)$. Inserting the maximisation condition $-c_{W} \cdot K=\rho$ and $\tau=c_{K} \cdot K$ into this gives the expression $\tau K=\rho W+\lambda c K$. See Sinn (2003) for a fuller exploration of this issue. 
public infrastructure is not sufficient to finance the cost of provision. The question of the state limiting itself to the selection principle has yet to be confirmed empirically but, we suggest, it is quite unlikely to be proven successful in the European social context.

\subsection{2 - Empirical Proof of the Infrastructure Argument}

Theoretically speaking, Borcherding and Decon (1972) suggest that city size and public goods expenditure are proportional, and so concludes that $\lambda$ is not less than zero, but in fact identically equal to it (see also Blankart, 1996). The authors assume, however, that the quality of the public goods provided is independent of city size, and when this assumption is relaxed, the results do show that $\lambda<0$. Brueckner (1981) echoes this result, and comes to a far more unambiguous conclusion, while explicitly accounting for size and quality. The study considers the provision of public fire bridges - measuring the quality of the protection they offer in terms of the size of private fire insurance premia - and theoretically illustrates that $\lambda<0$. To comfortably accept the infrastructure argument we would like to see some empirical evidence, but here we are disappointed as the evidence is quite scant. Many noteworthy scholars, working on tangents to this question, however, have indirectly contributed to the debate. The paper of Bretschger and Hettich (2002), for example, again proves useful to this end. Because although this study does not explicitly consider the question of infrastructure, it does consider the per capita income

level and unemployment levels in relation to social expenditure in 13 OECD countries over the period of 1980 to 1995 . The analysis shows that both the degree of openness and the level of capital are positive and significant in determining the amount of governmental expenditure, and that this expenditure is independent of per capita income and employment. The suggestion, therefore, is that governments will overspend at the cost of the immobile factor.

\section{Paper Position 3: The Infrastructure Argument}

Despite the difficulty in empirical proof, we consequently conclude on the basis of the strong theoretical foundations, that with the addition of infrastructure to the standard argument, in a situation of tax competition, only marginal benefit taxes on capital are possible, and that these are not sufficient to cover the cost of infrastructure. We therefore conclude that infrastructure causes capital to receive a net subsidy at the expense of immobile tax payers, so that tax competition not only implies a race to the bottom, but may also imply a race below the bottom; that is, a race to subsidise at source, and to move the economy towards point $\mathrm{H}$ in Figure 3.

\section{Tax Harmonisation: An Economic Panacea?}

On the basis of these arguments, the need for intervention appears obvious. In an influential report on harmful tax competition, however, the OECD recognised this fact, and suggests that there has to be an "[intensification of] international cooperation" (OECD, 1998). To this end, the report proposes (in the form of Recommendation 15) some strict guidelines for dealing with "harmful preferential tax regimes in member countries" (OECD, 1998); guidelines 
which include the creation of a tax haven blacklist, and the development of "the principles of good tax administration" through the political and economic links with these tax havens. The EU too has gotten in on the game, and despite being in 'talks' since as early as 1962, only published its recommendations on the matter in November 1997. In this, the European Commission recommended a 'coordinated action against tax competition in Europe' and has, as a declared purpose, the objectives of: reducing distortions still existing within the Single Market; avoiding losses on tax receipts; and establishing a tax structure more favourable of employment (Euro Comm, Bull. 6-1997). May $2^{\text {nd }} 2007$ saw a progress update, and in this it was tentatively suggested that a 'common base' could be in place some time "after 2010".

With both this and the OECD's proposals, however, the belief is that if capital is taxed excessively, it can escape from one country (à la Tiebout (1956)), but not from all countries. The authorities therefore expect to gain more power if they commit themselves to a policy of harmonisation, whereby tax rates are jointly determined and fixed above the competitive equilibrium set by policy competition. In doing so, harmonisation can be seen to allow the state to collect more revenue from capital and, simultaneously, to mitigate the distributional consequences to labour. Unfortunately, however, this line of reasoning is simply too good to be true, because despite its necessarily grandiose goals, tax harmonisation is a weak and dangerous instrument, and is likely only to backfire on its creators. The purpose of tax harmonisation is to provide a level European playing field, free from tax havens, and while we accept that harmonisation will achieve this, we suggest that there are always unexpected and unanticipated consequences from intervening in the free market. Every panacea has its side effects, and in this section we will attempt to identify a few of the obvious arguments.

\section{1 - The Collusive Agreements Argument}

Firstly, we suggest that tax harmonisation is not a sustainable solution because, according to the teachings of the game theorists, it is not a Nash Equilibrium (NEQ). The logic here is simple: to address this challenge posed by globalisation, the state must adapt. With tax harmonisation, the European Union is trying to do exactly this, and is taking on a policy position of "if you can't beat 'em, join 'em". Instead of acting like a state, and operating on the traditional model of what a state should be, tax harmonisation policies suggests that the state should act like a firm in an oligopolistic market, and should collude with its peers to raise 'prices' above the competitive market level. And at first glance, the logic of the argument seems sound. However, it is seriously flawed for at least two reasons. Firstly, and as established by Cournot (1851), one firm's best response to another's is never the collusive position, as there are always gains to be achieved by a unilateral deviation from the agreement. We see little reason to suspect that states acting like firms would be able to overcome this incentive problem which firms acting like firm can not themselves solve, and is so prevalent in the competitive market economy. As a case in point, we point to the prevalence of tax havens throughout Europe today, such as the

tiny, land-locked state of Liechtenstein; recently put under investigation by the German authorise for reasons of tax evasion (Süddeutsche Zeitung, 2008). Through a unilateral 
deviation from the collusive, cooperative position on tax evasion, Liechtenstein attracts 'investment' from Germany, as does Luxembourg, and the other so-called uncooperative tax havens dotted throughout Europe, like Andorra and Monaco (OECD, 2002).

We do not deny, however, that collusion is possible and practical, and fully accept that collusion between European states - in the form of tax harmonisation - could occur. A recent paper by Ivaldi et al (2003), for example, establishes a number of situations in which collusion between firms is probable. Amongst the numerous constraints suggested, however, it is shown that transparent markets with symmetric market shares, cost structures and capacity constraints are important factors in producing a cooperative outcome. In the case of a twenty-seven state $\mathrm{EU}$, however, we suggest that none of these conditions can and will be met, and so claim that the collusive outcome is not a natural outcome ${ }^{11}$. The vast differences in size that exists between Luxembourg and Germany, as well as the economic potential of the two, suggests that collusion in the form of harmonisation is simply improbable.

A collusive agreement could be made binding through the imposition of a credible threat (Kreps, 1990). If tax harmonisation was supported by EU law, for example, and if harsh financial retaliations or even economic sanctions could be imposed on 'tax transgressors', tax harmonisation could become a NEQ outcome and a cooperative solution could be induced between states. Because Luxembourg's economy is dependent upon Germany, Germany could credibly threaten Luxembourg with sanctions and induce cooperation, making tax harmonisation possible amongst the twenty-seven members. Even in this case, however, we suggest that few countries would subscribe to the agreement to the policy, and that tax harmonisation will not occur as a result. Tax harmonisation essentially creates a 'tax cartel' between states, but according to the literature on networks and alliances, the formation of a such cartel creates a public good, which induces positive externalities on those who remain outside the agreement (Stigler, 1950). The incentive therefore is to free-ride on the cartel formed by the other states, and to attract the 'investment' that it produces. Because of globalisation, these free-riders need not necessarily be EU states, and so even if all twenty-seven states could agree to tax harmonisation policies, countries in the European neighbourhood - such as Switzerland, Norway and Turkey - could benefit from a geographical closeness to the EU, and a significantly more competitive tax rate. In this case, participatory countries would loose out to nonparticipatory countries, and so no country would agree to the policy unless every country agreed. If the EU 'imposed' a tax harmonisation system, the result would be that the economic standing of the union would be undermined, and the benefit of membership would be devalued. In the world of globalisation, the proposal of tax harmonisation can therefore be seen to pose an existential threat to the European Union.

\section{2 - The Tax Game Argument}

\footnotetext{
${ }^{11}$ As evidence of these non-symmetric markets, consider that total GDP in Germany, in terms of 2006 purchasing power parity, for example, has been estimated to be in the region of $\$ 2.585 \mathrm{tn}$, while Luxembourg's GDP is about $\$ 40,577 \mathrm{bn}$. In per capital terms, Ireland's GDP was \$43, 000 in 2006, whereas France's was $\$ 30,100$, Poland's was $\$ 17,815$ and Romania's only $\$ 11,989$. (Eurostat)
} 
Secondly, we suggest that even if tax harmonisation was a NEQ between states, and even if it did not have positive externalities which created an existential threat for the EU, it would be an ill-advised policy move for the state, and would not benefit the participatory members. To see this, we consider the so-called 'tax game', presented in Baldwin and Krugman (2002). This study shows that, in a European Union of core-and-peripheral regions, tax harmonisation entails a shift from a non-cooperative tax game to a cooperative tax game, and can result in a Pareto improvement from the government's perspective. Such an improvement, however, can only occur, they suggest, in the absence of agglomeration, and with agglomerating forces, harmonisation will serve to make at least one, if not both regions, worse off. Two harmonising strategies are explored in the discussion: 'split-the-difference' tax harmonisation strategies, and the 'single-rate' strategies. In the case of the former, a common tax rate is adopted in both the core and peripheral regions; which lies between the two existing rates already levied in the industrial 'north' and peripheral 'south'. At this rate, however, and given the scale of the cost involved in any relocation decision, firms would have no incentive to move south, and so would prefer to stay agglomerated in the north. The 'split-the-difference' harmonisation strategy would therefore not shift the core from the north to the south, but would deprive the south of a major policy instrument - namely the corporate tax rate - which it can use to incentivise peripheral investment. Given that the south remains without industry in this scenario, its loss follows directly from the fact that its pre-harmonisation tax rate was an unconstrained maximum, and 'split-the-difference' is seen to favour the industrialised north. Compared to the initial equilibrium, however, the north too suffers substantial losses. The harmonisation of taxes in the north means that tax rates have been lowered, and the north now has a sub-optimal rate of corporate taxation. Harmonisation of this type is therefore seen to make both the core and the periphery worse off, and to succeed in nothing.

The alternative option would be to have 'single-rate' strategies in both regions. For example, by increasing both regions rates the north would, of course, gain because its taxcompetition constraint would be relaxed, and so could take advantage of its geographical appeal. Higher rates, however, would seriously disadvantage the south relative to the north, and stimulate a masse exodus. By contrast, lowering both rates would make both governments worse off; as neither region would collect the taxes that they could collect in isolation. In fact, any change in the southern equilibrium rate will lower the south's welfare, as measured by its government's objective function, and so it is easy to understand why there is no single rate that nations could agree upon. The tax rate of the core nation is constrained by competition, while that of the periphery nation is not, and consequently, there is no mutual gain to cooperation. Simply put, tax harmonisation cannot work in the presence of a core-periphery split.

Another study, by Fourçans and Warin (2001), also employs game theory to arrive at similar conclusions on the workability of EU wide tax harmonisation policies. This study suggests that if each country's tax policy is independent of the others, free riding behaviours will occur, as will a sub-optimal tax equilibrium for the monetary zone. However the paper points out that harmonisation may require some overly strict fiscal conditions - a sentiment reiterated in a 
study by Cremer and Gahvari (2000) - or the creation of a central coordination mechanism. Other studies, using similar techniques, have commented on required nature for this coordination. Suggestions have ranged from a central fiscal authority (Cardarelli, Taugourdeau and Vidal, 2002) to a stringent capital control mechanism (Rasmussen, 1997), all of which includes costs that are not currently considered by the debate.

\section{3 - The Overprovision Argument}

Thirdly, we suggest that even if tax harmonisation was a NEQ between states, which neither induced free-riding nor exacerbated the north-south divide, it would be an ill advised policy move, as it would result in an even greater transfer of the burden of taxation to the immobile factor of production. To see this, we consider the 'over-provision argument'.

One of the main problems with tax harmonisation is that it eliminates only one of two competition parameters available to the domestic government. Despite the fixing of the capital tax rate, labour taxation still leaves the free choice of how much public infrastructure to provide, and it is unclear whether the government will continue to choose an infrastructure $W$, compatible with the Samuelson condition, as outlined in Section Two. To see how the rent of the domestic population reacts to an increase in the provision of public infrastructure, given the capital tax rate, we differentiate the expression which shows that the total rent can also be expressed as the difference between the output and the sum of the interest cost in the imported capital, the total usage costs and the total cost of providing the public infrastructure $(R=f(K, L)-$ $r(K-\bar{K})-c(K, W) K-\rho W)$, and find:

$$
\begin{gathered}
\left.\left.\frac{d R}{d W}\right|_{\tau=\text { const }}=\left(f_{K}-r-c_{K} K-c\right) \Phi-c_{W} K-\rho\right) \\
\left.\Phi \equiv \frac{d K}{d W}\right|_{\tau=\text { const }}=\frac{c_{W}}{f_{K K}-c_{K}}>0
\end{gathered}
$$

where, $\Phi$ is the reaction coefficient for capital which results from implicitly differentiating the arbitrage condition, $f_{k}(K, L)=r+c(K, W)+\tau$, with a given $\tau$. The result is a coefficient which, it is suggested, is always strictly positive, and so an improvement in the infrastructure, with a given capital tax rate, is seen to attract more capital into the country. It follows then that, in the unconstrained equilibrium, $\tau-c_{k} \cdot K=0$ and $\rho+c_{w} \cdot K=0$. Thus, the national optimum condition, ( $\tau-$ $\left.c_{k} K\right) \Phi=\rho+c_{W} K$, would automatically hold if the harmonisation constraint on the national tax rate were not binding. With an effective constraint, however, which forces $\tau$ to obtain a value above the marginal congestion externality, $c_{k} \cdot K=0$, the left hand side of the expression is strictly positive, and then so too must the right hand side. The marginal willingness to pay, summed over all usage acts, is less than the cost of providing the infrastructure, indicating an oversupply of the infrastructure as measured by the Samuelson rule: $\mathrm{c}_{\mathrm{W}}(\mathrm{K}, \mathrm{W}) \mathrm{K}<\rho$. Given that capital is deterred by a tax rate higher than necessary to cover the marginal congestion externality, it 
pays domestic residents to lure more of it into the country by offering a better infrastructure. This, in turn, implies that more infrastructure will be provided than in a lassie faire equilibrium, wherein $\tau$ and $W$ were chosen competitively. Tax harmonisation is thus seen to intensify infrastructure competition between states, and to lead to an overprovision of the public infrastructure in equilibrium. This result is undesirable, not only from an efficiency perspective, but also from a distributional one. Because at least part of the extra tax revenue resulting from a harmonised tax rate increase will dissipate by financing the excessive amount of infrastructure at the expense, as always, of the fixed, labour factor of production.

\section{Paper Position 4: Tax Harmonisation}

Based on the three theoretical arguments outlined above, we conclude therefore that tax harmonisation could not, and would not, result in an equitable solution to the problems of tax competition. Firstly, tax harmonisation is not a NEQ policy as there are always greater gains available from a unilateral deviation; secondly, tax harmonisation induces positive externalities which will serve only to disadvantage subscribers to the policy relative to other parties, and may therefore undermine the stability of the Union as it devalues membership; thirdly, tax harmonisation will exacerbate regional economic differences and further divide the north and south; and finally, as evidenced by the overprovision argument, it will fail not only to address the tax burden imbalance, but will in fact exaggerate the situation under tax competition.

\section{An Alternative Solution?}

\section{1 - The Residence Principle}

Far from an economic panacea, our discussion suggests that tax harmonisation will not only exacerbate the current inequitable symptoms of tax competition, but result in a litany of unwanted side effects. However, the problem remains, and so in this section we introduce an alternative solution to the problem of harmful tax competition: the residence principle.

The solution of residence taxation has already been proposed in the OECD Model Double Tax Convention, and its superiority as a solution for destructive tax competition has also been discussed by Giovannini and Hines Jr (1990), and Bucovetsky and Wilson (1991). The latter's main conclusion, for example, is that "[...] it is the absence of this residence-based tax, rather than taxes on wage income, that is responsible for the tendency of decentralised decision-making by local governments to produce inefficiently low levels of taxation and public spending." (Bucovetsky and Wilson, 1991, 349-350). In short, under a system of source taxation, taxes on capital income are paid in the country where it is earned. As a result, firms, though residing in the same country, may face different tax rates, depending on the source of their income. Under a system of residence taxation, on the other hand, firms will pay the tax rate that is being levied in the country of their residence, irrespective of where the income is earned. Because of this, it is often said that source taxation is a tool in order to realise Capital Import Neutrality $(\mathrm{CIN})$ : regardless where the capital is coming from (i.e. the residence country), 
earnings are paid according to the source country's tax rate. The residence principle, however, realises Capital Export Neutrality (CEN) as it does not matter where the income is generated; all income is taxed according to the residence country's rate (Cnossen, 1987).

To illustrate, consider the model in Iwamoto and Shibata (1991) of a small open economy which faces a given world interest rate, $r$. In the absence of taxes, owners of capital invest up to the point where the marginal product of capital, $F_{k}$, equals the world interest rate. That is, $F_{k}=r$ is the arbitrage condition for all investors. Consider, however, that this country introduces a residence tax on capital income, where $\theta$ denotes the tax rate. Foreign residents keep the same arbitrage condition, $F_{k}=r$, whereas domestic residents now face a different after-tax rate of return (regardless where capital is invested), $\rho=(1-\theta) r$. However, their before-tax rate of return remains unchanged as they end up with an arbitrage condition of $(1-\theta) F_{k}=(1-\theta) r$, which can of course be reduced to the efficient condition $F_{k}=r$. To summarise, the response to the introduction of a residence tax is: $\rho=(1-\theta) r, F_{k}=r$. Now, consider the situation when this country would introduce a source tax rather than a residence tax on capital income. Investors will face a different tax rate per investment location and taxes are therefore levied on investment. With a tax rate of $\eta$, both domestic and foreign residents face an arbitrage condition of $(1-\eta) F_{k}=r$, which shows that, under source taxation, the investment decision is affected. Although the after-tax rate of return still equals the world interest rate, the before-tax rate of return differs sharply. In short, $\rho=r,(1-\eta) F_{k}=r$. Hence, "[t]he burden of a source tax appears only on the investment side of the economy", whereas "[l]oosely speaking, the burden of a residence tax falls upon the saving side of the economy" (Iwamoto and Shibata, 1991, 482).

Unfortunately, however, the situation is not as simple as depicted here. Sinn (1990) analyses the effects of introducing either a system of residence taxation or one of source taxation. Although he shows that the residence principle can indeed realise an efficient allocation of capital, this result is subject to an important additional condition: each country should uses the strict Schanz-Haig-Simons definitions of capital income. ${ }^{12}$ This implies that distortions from accelerated depreciation, non-taxed capital gains and other divergences from correct accounting must be excluded. Therefore, if the residence principle for capital taxation would be used as a solution for tax competition, the EU ought to implement the Schanz-HaigSimons definitions for capital income and profits.

\section{2 - Problems with and Criticisms of the Residence Principle}

Even though the economic theory that is outlined above indicates that the residence principle realises horizontal equity, its implementation would result in two difficulties.

The first problem is that although the residence principle eliminates tax competition in financial capital by realising horizontal equity, capital owners are all but indifferent towards their location of residence. In short, the realisation of CEN comes, by definition, at the cost of violating CIN. One can assume, however, that the realisation of CEN while violating CIN is

\footnotetext{
${ }^{12}$ Not looking at harmful tax competition, Sinn (1990) also shows that the source principle, too, can result in an efficient allocation of capital. However, whereas the residence principle requires true economic depreciation to realise efficiency, the source principle needs an immediate write-off.
} 
better than vice versa. ${ }^{13}$ While it is true that CIN prevents tax competition by changing the location of residence, CEN creates horizontal equity and, therefore, eliminates tax competition through investment decisions, which is much more sensitive to differences in tax rates. It is reasonable to assume that the responsiveness of financial capital is much higher than that of real capital, i.e. equipment and machinery (Keen, 1993). Moreover, Europe's labour force is well-known for its reluctance to relocating to another country. Even though large differences in unemployment rates and wages should, in theory, result in relocation of the labour force, cultural barriers and the like seem to form considerable costs, hence limiting European labour mobility (e.g. Baldwin and Wyplosz, 2004). ${ }^{14}$ Besides this, relocating real capital can easily be assumed to be far more costly than relocating financial capital. Closing plants in one country and opening plants in another has huge corresponding financial costs and, taking into account social-political resistance, might take years to complete. As a result of the relatively low mobility of both labour and real capital, we suspect relatively little tax avoidance as a result of the violation of CIN, compared to the violation of CEN, in the short run. In the long run, however, relocating real capital and labour is suspected to be easier and cheaper. Therefore, Gorter and de Mooij (2001) argue that the welfare loss associated with a violation of CEN is determined by the sensitivity of capital across space, whereas the welfare loss of violating CIN depends on the sensitivity of saving across time, determined by the inter-temporal elasticity of substitution. The research on this empirical question suggests that distortions in the allocation of capital are relatively large to the inter-temporal distortions, indicating that violating CEN is more distortive than violating CIN (Gorter and de Mooij, 2001).

The second problem of eliminating tax competition by implementing the residence principle considers the exchange of information. A drawback to the residence principle that is regularly mentioned is that it makes tax evasion relatively easy. Investors, on one hand, obviously have an incentive to conceal their income from the residence country, resulting in a higher after-tax income. On the other hand, without further arrangements, by not providing information to foreign tax authorities, source countries make themselves more attractive to foreign investors as it reduces the tax base of foreign investors. As a result, under the residence principle it might be in the best interest for source countries not to disclose tax information to residence countries. There are, however, a number of reasons why countries might voluntarily engage in sharing tax-relevant information.

In a reputation game, source countries will also derive benefits from information sharing, as they will increase the likelihood of given tax information themselves. In such a game, countries face a trade-off between the costs, i.e. reduced attractiveness for foreign investors, and benefits, i.e. increase in tax revenue from abroad, associated with information sharing. Bacchetta and Espinosa (1995) show that it may be in the best interest of countries to provide some, but not all, information. However, when countries are asymmetric in size, large countries

\footnotetext{
${ }_{14}^{13}$ See for example Giovannini et al. (1989)

${ }^{14}$ Moreover, concerning labour mobility, Bentivogli and Pagano (1999) show that Europeans are more risk averse than Americans, whose flexibility is an important factor driving the relative success of the United States' economy (Zimmermann, 2005).
} 
might be more willing to cooperate than small countries. ${ }^{15}$ The reason is that the tax base of residents is large compared with foreign investment. In contrast, small countries might have little incentive to cooperate, which can explain why tax havens are often relatively small countries. Changing the settings used in Bacchetta and Espinosa (1995) might induce countries to provide more information. In a regime of tacit cooperation, countries can be voluntarily induced to share tax-relevant information (Keen and Ligthart, 2006a). In an infinitely repeated game countries can either choose to sustain cooperation by fully providing tax information to residence countries or choose to deviate from the strategy by not providing (full) information. Cooperation might sustain if the punishment for violating is sufficiently high. Each country balances the temporary benefits from deviating with the costs from this non-cooperative behaviour forever after. Given that defecting in one period will yield higher tax income, cooperation will only be sustainable if and only if countries put sufficient weight on future tax income.

Countries will also be induced to voluntarily exchange information with foreign tax authorities in a revenue-sharing scheme. By giving some of the additional earned tax revenue through information sharing, residence countries create an incentive for source countries to share their information. This regime is analysed in Keen and Ligthart (2006b), taking into account asymmetry in size, and it is concluded that it may be in the best interest of large countries to share some of their proceeds from information exchange with small countries to make sure that the latter gain from sharing information and will hence voluntarily exchange information. $^{16}$

Establishing a regime of effective information exchange will, however, face political opposition because it deals with, mostly confidential, tax information. ${ }^{17}$ Tax authorities need to have the legal capacities both to acquire tax information from non-residents and to share this information with the respective cooperative countries. Moreover, problems will occur when third countries are unwilling or unable to satisfy these conditions, e.g. when bank information is to be kept a commercial secret. Unwillingness to cooperate might be expected from tax havens which benefit from an inflow of financial capital by offering the possibility to hide income from tax authorities. This third country problem greatly reduces the incentives of countries to engage in information exchange. It is the background of these difficulties that ought to be kept in mind when looking at the European Council's initiative for a Savings Tax Directive. ${ }^{18}$ The Directive, which came into force July 1, 2005, aims to enable savings income in the form of interest payments made in one Member State to beneficial owners who are individuals resident in another Member State to be made subject to effective taxation in accordance with the laws of the latter Member State. Moreover, the Directive establishes a regime of effective information exchange by obliging all Member States to automatically exchange information on interest payments by paying agents established in their territories to individuals resident in other Member States. The Directive, however, does not apply a pure residence principle as it allows 3

\footnotetext{
${ }^{15}$ See Keen and Ligthard (2006a; 2007)

${ }^{16}$ See also Keen and Ligthart (2007)

${ }^{17}$ See for example Rahn and de Rugy (2003)

${ }^{18}$ 2003/48/EC.
} 
countries not to automatically exchange information because of 'structural differences' and to levy withholding taxes. ${ }^{19}$ The tax rate of this withholding tax is fixed and 75 percent of its revenue must be transferred to the residence country. Although this innovating revenue-sharing scheme is a big step forward with respect to sharing tax-relevant information between Member States, it is not a strict implementation of the residence principle and, therefore, violates CEN.

\section{Paper Position 5 - The Residence Tax}

On the basis of the arguments outlined above we believe that a change in the tax base towards pure resident's taxation is a superior, but not flawless, alternative to that of tax harmonisation. However, the residence principle violates Capital Import Neutrality and heats up the discussion on sharing tax-relevant information among countries. The Savings Tax Directive is a step towards a regime of effective information exchange, but is not the panacea for the problem of harmful tax competition as it is no strict implementation of the residence principle.

\section{Discussion AND CONCLUSION}

The purpose of this paper was a simple one: firstly, to prove that tax competition was occurring during to the increased mobility of capital; secondly, to prove that the process was harmful and resulted in an unfair burdening of the labour element; thirdly, to prove that the European Commissions tax harmonisation proposal was not the panacea it is suggested to be; and finally, to discuss alternative solutions to harmful tax competition.

Of these, the first two purposes were fulfilled with concrete empirical evidence, and we illustrated both the process of tax competition over time, and the successive transfer of the tax burden to the immobile, labour element. In attempting the third objective, we first showed that the implementation of a tax harmonisation scheme is not feasible, as it will result in positive externalities for those not party to the agreement. We suggested that tax harmonisation will result only in a disadvantage to the members of the European Union relative to their neighbours, and may devalue the advantages of Membership. In the worst case scenario, we noted that tax harmonisation may, according to the literature of networks, disincentivise Membership of the European Communities. However, we accepted that while states harmonising taxes are similar to firms harmonising prices, the theories of industrial organisation might not necessarily be transferable to the state. We proceeded therefore, to illustrate other prominent reasons not to harmonise taxes. In doing so we showed that tax harmonisation will: firstly, exacerbate the economic core-and-periphery divisions already so prominent in the union of twenty-seven; and secondly, result in the over provision of infrastructure, all at the cost of the labour element. On the basis of these arguments, we suggest then that European level tax harmonisation plans will exaggerate regional economic differences, and burden the labour element with even greater tax responsibilities than suffered now in a position of harmful tax competition.

\footnotetext{
${ }^{19}$ Austria, Belgium and Luxembourg are subject to a transition period in which they levy a withholding tax of 15 percent in the first three years, 20 percent in the next three years, and 35 percent thereafter, until third countries, including the U.S. and Switzerland, apply measures equivalent to, or the same as, those provided by the Directive.
} 
With the completion of this, our discussion was then in the position it had begun from. In this position, tax competition was occurring to the detriment of both the state and the labour element of production, relative to the mobile capital of the multinational, and demanded a solution. At this point therefore, we introduced the concept of a shift in the tax base from mixed taxes (residence and withholding) to pure residential taxation as an alternative solution. As the residence principle creates horizontal equity among investors it realises Capital Export Neutrality (CEN) and, therefore, eliminates tax competition through investment decisions. The residence principle, however, is not a flawless solution to the problem of tax competition as it gives rise to two problems. First, although the residence principle realises CEN it violates Capital Import Neutrality (CIN), i.e. it does matter where the investment comes from. Investors may relocate to another residence country in order to realise the highest after-tax gain. However, there is reason to believe that a violation of CIN is not as harmful as a violation of CEN because the sensitivity of real capital and individuals to differences in tax rates is lower than that of financial capital. A second problem with implementation of the residence principle is that, in order to work properly, it requires a regime of effective exchange of tax-relevant information. However, notions of privacy and differences in political preferences keep, as of yet, certain source countries from exchanging information to tax authorities in residence countries. The introduction of the Savings Tax Directive is a step towards improving information sharing between the Community's tax authorities. However, the Directive does not realise a strict implementation of the residence principle as exceptions are made for countries that, because of 'structural differences' cannot apply the automatic exchange of information. Consequently, the Directive does not guarantee Capital Export Neutrality and is therefore no final solution to the problem of harmful tax competition.

In conclusion, we have shown that tax competition is occurring, harmful, and not to be solved by rate harmonisation. Initiatives of the OECD and the European Council to eliminate tax competition may not have resulted in a panacea yet, but indicate recognition of the problem. Implementation of the residence principle is a theoretical plausible solution to the problem, but gives also rise to several practical problems. Further legal and economic research, as well as political negations may, however, eventually result in the long-awaited panacea, and with this paper we hope to have contributed to that end.

\section{BIBLIOGRAPHY}

Altshuler, R., Grubert, H. and S. Newlon, 2001. Has U.S. Investment Abroad Become More Sensitive to Tax Rates? In: Hines Jr., J.R. (ed.), International Taxation and Multinational Activity. Chicago, IL: University of Chicago Press.

Anderson, S., and J. Cavanagh, 2000, The Rise of Corporate Global Power, Institute for Policy Studies, Working Paper

Bacchetta, P., and Espinosa, M.P., 1995. Information sharing and tax competition among governments, Journal of International Economics 39, 103-121.

Baldwin, R. and Krugman, P., 2002. Agglomeration, Integration and Tax Harmonization, NBER Working Paper 9290.

Baldwin, R. and Wyplosz, C., 2004. The Economics of European Integration. London: McGrawHill.

Bentivogli, C. and Pagano, P., 1999. Regional Disparities and Labour Mobility: the Euro-11 versus the USA. Labour 13(3), 737-760.

Berglas, D., and Pines, D., 1981. Clubs, Public Goods and Transportation Models, Journal of Public Economics 15(2), 141-162. 
Blankart, Ch. B., 1996, BrauchtEuropamehr zentralstaatliche Koordination? Eininge Bermerkungen zu Hans-Werner Sinn, Wirtschaftsdienst 76 (2) 87 - 91

Bretschger, L., and Hettich, F., 2002. Globalisation, Capital Mobility and Tax Competition: Theory and Evidence for OECD Countries, European Journal of Political Economy 18(4), 695-716.

Broadway, R., 1980. A Note on the Market Provision of Club Goods, Journal of Public Economics 13(1), 131-137.

Broekman , P. and W.N. van Vliet 2001, Winstbelasting en Kapitaalstromen in de EU, Openbare Uitgaven 33, 46-53.

Brueckner, J.K., 1981. Congested Public Goods: The Case of Fire Protection, Journal of Public Economics 15(1), 45-58.

Buchanan, J.M., 1965. An Economic Theory of Clubs, Economica 32(125), 1-14.

Bucovetsky, S., 1991. Asymmetric Tax Competition, Journal of Urban Economics 30(2), 167-181.

Bucovetsky, S., and J.D Wilson, 1991. Tax competition with two tax instruments, Regional and Urban Economics 21(3), 333-350.

Cardarelli, R., Taugourdeau, E. and Vidal, J.P., 2002. A Repeated Interactions Model of Tax Competition, Journal of Public Economic Theory 4(1), 19-38.

Cnossen, S., 1987. Tax Coordination in the European Community, Deventer: Kluwer.

Cournot, A., 1851. Researches into the Mathematical Principles of the Theory of Wealth. New York: MacMillan.

Cremer, H. and Gahvari, F., 2000. Tax Evasion, Fiscal Competition and Economic Integration, European Economic Review 44(9), 1633-1657.

Devereux, M., 1992. The harmonisation of corporate income taxes in Europe: the Ruding Committee Report, Fiscal Studies, Institute for Fiscal Studies, vol. 13(2), pages 108-121, May.

Devereux M., and S. Loretz, 2007. The Effects of EU Formula Apportionment on Corporate Tax Revenues, Working Papers 0706, Oxford University Centre for Business Taxation

Dvereux, M., and H. Freeman, 1991. A general neutral profits tax, Fiscal Studies, Institute for Fiscal Studies, vol. 12(3), pages 1-15

Devereux, M., and R. Griffith, 1998. The taxation of discrete investment choices, IFS Working Papers W98/16, Institute for Fiscal Studies

Dharmapala, D and Hines, J., 2006. Which Countries Become Tax Havens? NBER Working Paper No 12802

Drucker, P.F., 2005. Trading Places, The National Interest 79.

Edward, C., and de Rugy, P., 2002. International Tax Competition: A $21^{\text {st }}-$ Century Restraint on Government. Policy Analysis 12, 1-43.

Fourçans, A., and Warin, T., 2001. Tax Harmonization versus Tax Competition in Europe: A Game Theoretical Approach, Centre for Research on Economic Fluctuations and Employment, Working Paper No. 132.

Garrett, G., 1995. Capital Mobility, Trade and the Domestic Politics of Economic Policy, International Organisation 49(4), 657-687.

Genschel, P., 2002. Globalization, Tax Competition and the Welfare State. Politics \& Society 30, 245-275.

Genschel, P. and Plümper, T., 1997. Regulatory Competition and International Cooperation. Journal of European Public Policy 4(4), 626-642.

Giovannini, A., Malinvaud, E. and Mayer, C., 1989. National tax systems versus the European capital market, Economic Policy 4(9), 345-386.

Glomm, G., and Lagunoff, R., 1998. A Tiebout theory of public vs. private provision of collective goods, Journal of Public Economics 68(1), 91-112.

Gorter, J. and de Mooij, R.A., 2001. Capital income taxation in Europe: Trends and trade-offs. CPB Working Paper.

Grubert H., and J. Mutti (1991), Taxes, Tarriffs and Transfer Pricing in Multinational Corporation Decisions Making, Review of Economics and Statistics 73: 285-293

Hines, J., 1999. Lessons from Behavioural Responses to International Taxation, National Tax Journal 52(2), 305-322.

Hines, J. \& E.M. Rice, 1994. Fiscal Paradise: Foreign Tax Havens and American Business, NBER Working Papers 3477, National Bureau of Economic Research, Inc.

Hirshleifer, J., 1983. From Weakest Link to Best Shot: The Voluntary Provision of Public Goods. Public Choice 41(3), 371-386. 
Hirshleifer, J., 1984. The Voluntary Provision of Public Goods - Descending-Weight Social Composition Functions. UCLA Working Paper 326, available at: http://www.econ.ucla.edu/workingpapers/wp326.pdf.

Ivaldi, M., Jullien, B., Rey, P., Seabright, P. and Tirole, J., 2003. The Economics of Tacit Collusion, Final Report for DG Competition, European Commission.

Iwamoto, Y., and Shibata, A.,1991. Capital income taxation and the current account in a small open economy, Journal of International Money and Finance 10(4), 480-496.

Keen, M., 1993. The Welfare Economics of Tax Coordination in the European Community: A Survey, Fiscal Studies 14(2), 15-36.

Keen, M. and Ligthart, J.E., 2006a. Information Sharing and International Taxation: A Primer. International Tax and Public Finance 13, 81-110.

Keen, M. and Ligthart, J.E., 2006b. Incentives and Information Exchange in International Taxation. International Tax and Public Finance 13, 163-180.

Keen, M. and Ligthart, J.E., 2007. Revenue Sharing and Information Exchange under Nondiscriminatory Taxation. Scandinavian Journal of Economics 109(3), 487-504.

Kreps, D., 1990, Game Theory and Economic Modelling. Oxford University Press

Mohring, H., and Harwitz, M., 1962. Highway Benefits, An Analytical Framework. Evanston, III.: Northwestern University Press.

Mueller, D.C., 2003, Public Choice III, $3^{\text {rd }}$ Edition, Cambridge University Press

Oates, W.E., and Schwab, R.M., 1988. Economic Competition Among Jurisdictions: Efficiency Enhancing or Distortion Inducing?, Journal of Public Economics 35(3), 333-354.

OECD, 1998, Harmful Tax Competition: An Emerging Global Issue

Quinn, D., 1997. The Correlates of Change in International Financial Regulation, American Political Science Review 91(3), 531-551.

Rahn, R.W. and de Rugy, V., 2003. Threats to Financial Privacy and Tax Competition. Policy Analysis 491, 1-14.

Rasmussen, B. S., 1997. International Tax Competition Tax Cooperation and Capital Controls. University of Aarhus Department of Economics Working Paper 1997-9. Available at SSRN: http://ssrn.com/abstract $=8744$.

Roin, J., 2001. Competition and Evasion: Another Perspective on International Tax Competition, Georgetown Law Journal 89, 543-604.

Schmitz, S., (2002), The European Commission's Decision in GE/Honeywell and the Question of the Goals of Antitrust Law, Journal of International Economic Law 23 539, Fall 2002

Simmons, R., 2006. Does recent empirical evidence support the existence of international corporate tax competition?, Journal of International Accounting, Auditing and Taxation 15(1), 16-31.

Sinn, H.W., 1990. Tax harmonization and tax competition in Europe, European Economic Review 34, 489-504.

Sinn, H.W., 1997. The Selection Principle and Market Failure in Systems Competition. Journal of Public Economics 66(2), 247-274.

Sinn, H.W, 2003. The New Systems Competition. Malden, MA: Blackwell Publishing.

Smith, A., 1776. The Wealth of Nations. New York: Modern Library.

Stigler, J.G., 1950. Monopoly and Oligopoly by Merger, American Economic Review 40(2), 23-34.

Sullivan, L., 1995. Post-Chicago Economics. Antitrust Law Journal 63, 669-682.

Sullivan, M., 2002. Data Show Europe's Tax Havens Soak Up U.S. Capital, Tax Notes February 42002.

Swank, D., 1998. Funding the Welfare State: Globalisation and the Taxation of Business in Advanced Market Economies, Political Studies 46(4), 671-692.

Tiebout, C., 1956. A Pure Theory of Local Expenditures. The Journal of Political Economy, 64(5), 416-424.

de Tocqueville, A., 1840, Democracy in America, trans. and eds., Harvey C. Mansfield and Delba Winthrop, University of Chicago Press, 2000

UNCTAD, 2002 World Investment Report: Transnational Corporations and Export

Competitiveness

Walzer, N., 1972. Economics of Scale and Municipal Police Services, Review of Economics and Statistics 54(4), 431-438.

Winner, H., 2005. Has Tax Competition Emerged in OECD Countries? Evidence from Panel Data, International Tax and Public Finance 12(5), 667-687.

Zimmerman, K.F., 2005. European Labour Mobility: Challenges and Potentials. De Economist $153(4), 425-450$. 